\section{Spread and Liquidity Issues: A markets comparison}

\section{Sebastjan Strašek}

Faculty of Economics and Business, University of Maribor, Slovenia sebastjan.strasek@um.si

\section{Bor Bricelj}

Faculty of Economics and Business, University of Maribor, Slovenia bor.bricelj@um.si

\begin{abstract}
The financial crises are closely connected with spread changes and liquidity issues. After defining and addressing spread considerations, we research in this paper the topic of liquidity issues in times of economic crisis. We analyse the liquidity effects as recorded on spreads of securities from different markets. We stipulate that higher international risk aversion in times of financial crises coincides with widening security spreads. The paper then introduces liquidity as a risk factor into the standard value-at-risk framework, using GARCH methodology. The comparison of results of these models suggests that the size of the tested markets does not have a strong effect on the models. Thus, we find that spread analysis is an appropriate tool for analysing liquidity issues during a financial crisis.
\end{abstract}

Key words: liquidity, financial crisis, GARCH VaR models

\section{Introduction}

Traditionally, liquidity risk in financial crisis stemmed from the possibility of bank runs. One can find a number of these episodes. Strahan (2012) pointed out that, more recently, liquidity risk has come less from deposit outflows and more from exposure to a range of lending and interbank financial arrangements. These include undrawn loan commitments, obligations to repurchase securitized assets, margin calls in the derivatives markets, and the withdrawal of funds from wholesale short-term financing arrangements.

The global crisis has brought forward concerns that the lack of funding liquidity can have serious negative consequences, which can range from firms' inability to sell commercial papers to finance their business models to borrowers' inability to obtain funding for home mortgages. Falling home and stock prices are then unavoidable effects. Unconventional measures have been introduced to mitigate this problem: The Fed's decision to purchase unsecured 90-day commercial paper directly from corporations in late October 2008 and the \$1,25 trillion home mortgage bond purchase program in 2010 are examples of solving the balance sheet channel (Bernstein, Hughson, \& Weidenmeier, 2011).

In searching for other important effects of changes in funding liquidity on financial markets, Brunnermeier and Pedersen (2009) explored the relationship between
ORIGINAL SCIENTIFIC PAPER

RECEIVED: SEPTEMBER 2015

REVISED: DECEMBER 2015

ACCEPTED: DECEMBER 2015

DOI: 10.1515/ngoe-2016-0001

UDK: 338.124.4:339.721

JEL: C19, E44, G01

Citation: Strašek, S., \& Bricelj, B. (2016). Spread and Liquidity Issues: A markets comparison. Naše gospodarstvo/Our Economy, 62(1), 3-11. DOI: 10.1515/ ngoe-2016-0001

\section{NG OE}

NAŠE GOSPODARSTVO OUR ECONOMY

\begin{tabular}{l|l|l} 
Vol. 62 No. 12016 \\
\hline
\end{tabular}

pp. 3-11 
funding liquidity and market liquidity. Their analysis suggested that market liquidity is likely to be low when funding liquidity is low. The sub-prime mortgage crisis and global crisis are examples in which funding constraints have played an important role in the onset and spread of the financial crisis.

A disagreement exists among economists as to whether the global crisis was a liquidity crisis or a solvency crisis. We could also find ample evidence that liquidity risk is incorporated into asset prices that allows the possibility that illiquidity and insolvency are not as distinct phenomena as we usually think (Viral \& Pedersen, 2004).

The idea that the crisis was a liquidity crisis is based on the Diamond-Dybvig model of bank runs, where repo customers conducted a fire sale of repo securities, preventing banks from being able to borrow for the short term. The opposite argument states that banks' liquidity dried up simply because the market realized that the banks were insolvent.

Mehrling (2013) warned of the risk of over-simplification, where we tend to think of the financial crisis as a credit crisis concentrated in the banking system when in fact the global crisis was a liquidity crisis that prompted a solvency crisis on the dealer market. Far more important than a bank-based lending system for global financial markets is market liquidity, which can be defined as the ability to buy or sell securities in large quantities with virtually no effect on the price.

In the run-up to the crisis, huge incentives existed to set up or expand shadow banks because interest rates were low and there was a growing flow of available assets. The problem was that riskier assets in the form of securitized subprime mortgages filtered into the system (Mehrling, 2013). Forced sales provoked declining prices and, at one point, only the Fed's intervention prevented huge implications for the dealer funding market.

The global crisis of 2008 developed momentum and transformed to the euro area sovereign bond crisis. It is interesting that liquidity played a minor role in bond yield determination until 2008, after the Lehman crisis, and this role was quickly reduced after late 2009 (Bai, Julliard, \& Yuan, 2012). In other words, during the early stage of the euro sovereign crisis, the market was characterized by flight to liquidity, but in later stages, credit risk was the main driver of bond yields and the market was characterized by flight to quality.

VAR analyses (Bai et al., 2012) also indicated that the euro sovereign bond crisis was less of a liquidity crisis and instead a crisis induced by common fundamentals. Imprudent fiscal policies (Greece) and lax regulation in the private sector like imprudent banking policies (Ireland and Slovenia), housing booms (Spain), and other fundamental factors provoked bad domestic macroeconomic behaviour. The liquidity crisis was an inevitable implication of such fundamental disequilibria.

\section{Spread Considerations}

In line with existing empirical literature, the financial crises are closely connected with spread changes. Here we have in mind different types of spreads, like sovereign bond yield spreads, credit spreads of various financial instruments, and bid-ask spreads on asset prices.

It is not surprising that, in this environment, the crisis spreads were not only widening but also reaching record highs. The dimensions of risk measured by spreads may be many, but they can be grouped as being either default or liquidity risks. The empirical evidence has identified three main common drivers of bond yields and yield spreads: (i) credit risk (comprising the default risk, the credit spread risk, and the downgrade risk), (ii) liquidity risk, and (iii) global risk aversion. The euro sovereign crisis revealed that all three types of risk are reflected in the yields and yield spreads on government bonds.

Research on the determinants of sovereign bond yields differentials in the euro area has shown that government bond yields have risen sharply since the beginning of the financial crisis. Differences between euro area countries have become more pronounced as the spreads of some countries widened much more that those of other countries. Attinasi, Checherita, and Nickel (2009) found that sovereign bond yield spreads in the Eurozone reflect concerns about a country's credit risk and liquidity risk as well as higher international risk aversion. Higher expected budget deficits and/or higher expected government debt relative to Germany have contributed to higher government yield spreads in the Eurozone between the end of July 2007 and the end of March 2009. Empirical findings (Barrios, Iversen, Lewandowska, \& Setzer, 2009) confirmed that international factors, particularly general risk perception, play a major role in explaining government bond yield differentials. The role played by domestic factors is smaller, but non-negligible. The impact of domestic factors on bond yield spreads increased significantly during the crisis, when international investors started to discriminate more between countries.

Empirical studies (De Grauwe \& Ji, 2013) tested the hypothesis that government bond markets in the eurozone are more fragile and more susceptible to self-fulfilling liquidity crises than in stand-alone countries. A key difference exists between EMU member countries and stand-alone countries in terms of countries issuing debt in their own currency: 
Figure 1: Spreads and debt-to-GDP ratios of stand-alone countries

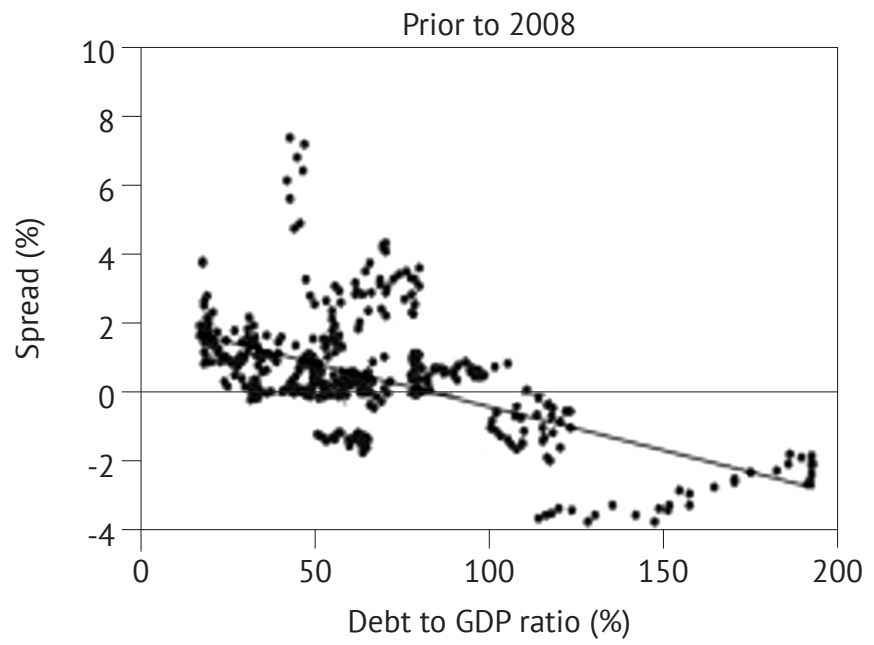

Source: De Grauwe and Ji (2013).

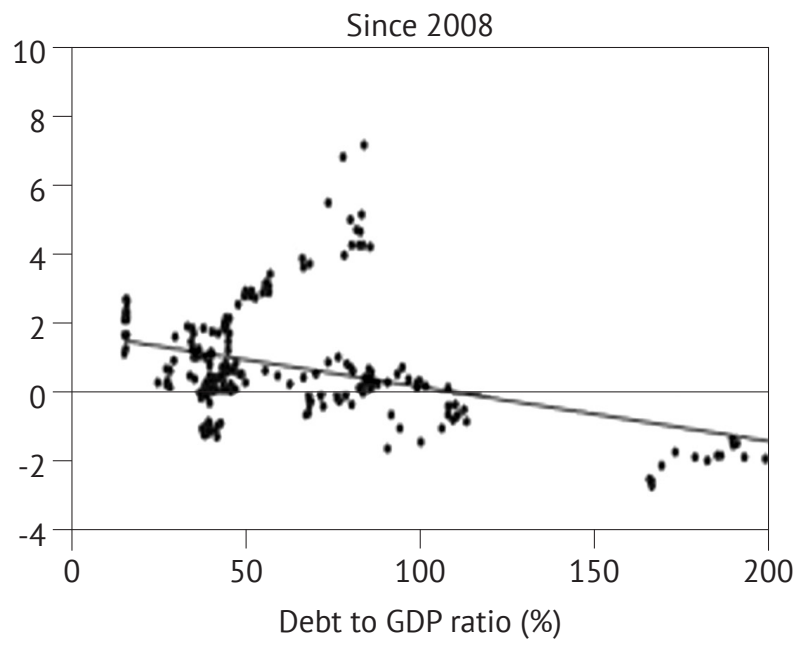

Empirical data show that, despite the fact that in stand-alone countries' debt-to-GDP ratios and fiscal space variables were equally high and increasing, the spread movement did not follow the member countries' scenario.

The trap for members of a monetary union is that they issue debt in a currency over which they have no control and cannot give a guarantee that the cash will always be available to pay out bondholders at maturity. De Grauwe and Ji (2013) warned that such a liquidity crisis in a monetary union also makes it possible for the emergence of multiple equilibria. Undoubtedly, a great contrast exists between the eurozone and the stand-alone countries: Since the start of the financial crisis, the line between spreads and debt-to-GDP ratios has remained equally weak for stand-alone countries; furthermore, financial markets appear to punish eurozone countries more for the same imbalance. These conclusions are in line with De Grauwe's (2011) findings, which support the idea that government bond markets are more fragile and more susceptible to self-fulfilling liquidity crisis than standalone crisis.

The large relevance is associated with the combination of high risk aversion and large current account deficits, as the latter tends to magnify the incidence of deteriorated public finances on government bond yield spreads. Barrios et al. (2009) found that countries with large current account deficits experience an 11-base-point increase in government bond yield spread for each additional percentage point deterioration in public deficit. A high interaction occurs between general risk aversion and domestic fiscal conditions. In countries with large current account deficits and high debt, the latter experience the highest bond yield increases as a consequence of deteriorating public finances and increases in general risk aversion.

Different authors have also suggested that differences in government bond market liquidity have also been found to be significant for many euro area countries. Beber, Brand, and Kavajez (2006) found that, although credit risk matters for bond valuation in normal times, liquidity becomes more important in times of financial stress. The global crisis confirmed that the liquidity of government bond markets played a role in the widening of sovereign bond yield spreads. Countries with a more liquid bond market seem to enjoy relatively lower bond yield spreads during periods of financial turmoil (Attinasi et al., 2009).

The information contained in spreads is important because it may be indicative of an important channel through which financial prices affect the real side of the economy. The econometric analyses of the changing dynamic properties of a number of commonly reported yield spreads series (Guidolin \& Tam, 2010) confirmed the use of spreads in timing breakpoints of selected financial crises. These findings suggest that, in non-crisis periods and especially in the aftermath of the crisis, yield spreads tend to adjust upward for yields on high (low) default (liquidity) risk bonds and downward for yields on high (low) default (liquidity) risk bonds.

Calculations on the relative contribution of explanatory variables to the change in average sovereign bond spreads relative to Germany show (Checherita, Attinasi, \& Nickel, 2010) that the liquidity proxy amounts to $14 \%$. The other proportions are: international risk aversion at 56\%, expected fiscal position (expected budget balance and debt) at 21\%, and the announcement of bank rescue packages at $9 \%$. The authors also found that the announcement of bank rescue packages proved to be a robust and statistically significant determinant of the differential between sovereign credit 
default swap premia and the iTraxx financials. This finding suggests that government commitments to support ailing financial institutions led to a re-assessment of sovereign credit risk on the part of the investors through a transfer of risk from the banking sector to the government (Checherita et al., 2010).

Gilchrist and Zakrajsek (2012) found that, as a feature of a business cycle, the number of yield spreads tends to widen shortly before the onset of recessions and to narrow again before recoveries. This phenomenon is due to the fact that credit risk spreads measure the default risk on private (relatively risky) debt. Hence, if private lenders can accurately assess increased default risks for individual firms or industries, these changes will be reflected by increases in the spreads. On the other hand, broad-based bank rescue packages alleviate some credit risk in the banking sector and bring about a transfer of credit risk from the private financial to the public sector. This fact was best seen in the global crisis, when a sharp increase in sovereign credit default swap (CDS) premia for most euro area countries was realized, whereas the CDS premia for European financial corporations (i.e., those covered by iTraxx financial index) reversed their upward trend and started to decline (ECB, 2009).

As illustrated in Figure 3, major investment banks experienced spreads that widened dramatically through the second half of 2007 and continued to widen still further through 31 October 2008. This corresponded to the movement of the spread between Libor and the overnight index swap (OIS) rate, which increased from less than 14 base points in July 2007 to 346 points on October 2008. Another argument for widened spreads represents the spread between Libor and the Treasury bill rate (TED), which widened from an average of 38 base points in the pre-crisis period to 464 points on 10 October 2008. Moreover, the same scenario could be observed on the yield spreads of short-term commercial paper of both non-financial and financial firms over the Treasury rate and spreads between 3-month Eurodollar deposits and the Treasury. Finally, the yield spreads of both MBS and high-yield bonds over the 10-year bond also rose considerably after July 2007. Pringle and Carver (2009) suggested that the spreads indicate that the market considered MBS to be even riskier than high-yield bonds, which was not the case prior to that time.

Liquid markets tend to exhibit five characteristics: tightness, immediacy, depth, breadth, and resiliency. Tightness refers to low transactions costs, such as the difference between buy and sell prices, like the bid-ask spreads in quote-driven markets. Several factors contribute to the difference between the bid and ask prices-namely, the security's liquidity, volatility, and stock price. The global liquidity crisis that started in 2007 could be explained through bid-ask spreads as a measure for the evolution of market liquidity. Pedersen (2009) highlighted the close co-movement between bid-ask spreads and VIX throughout the crisis as well as the visible connection to the TED spreads, indicating a link among market liquidity, funding, and volatility.

Figure 2. Cumulative changes in average five-year sovereign credit default swap premia for Eurozone countries and iTraxx financial index (15 September 2008 to 25 March 2009; bps)

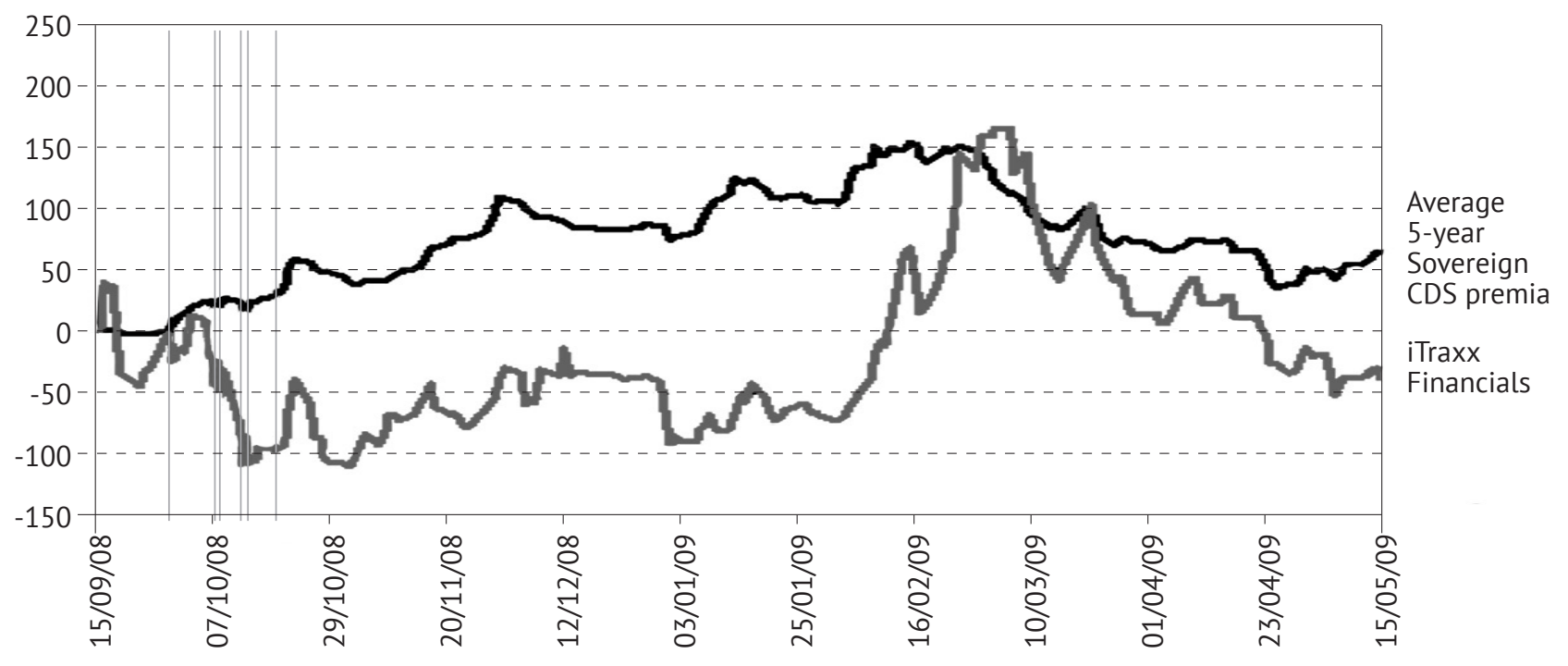

Note: The vertical bars indicate the dates on which bank rescue packages were announced in Eurozone countries. Countries included in the analysis: Austria, Belgium, Finland, France, Germany, Greece, Ireland, Italy, Netherlands, Portugal, and Spain.

Sources: Datastream and ECB staff calculations. 
Figure 3: Bid-ask spreads during the global liquidity crisis

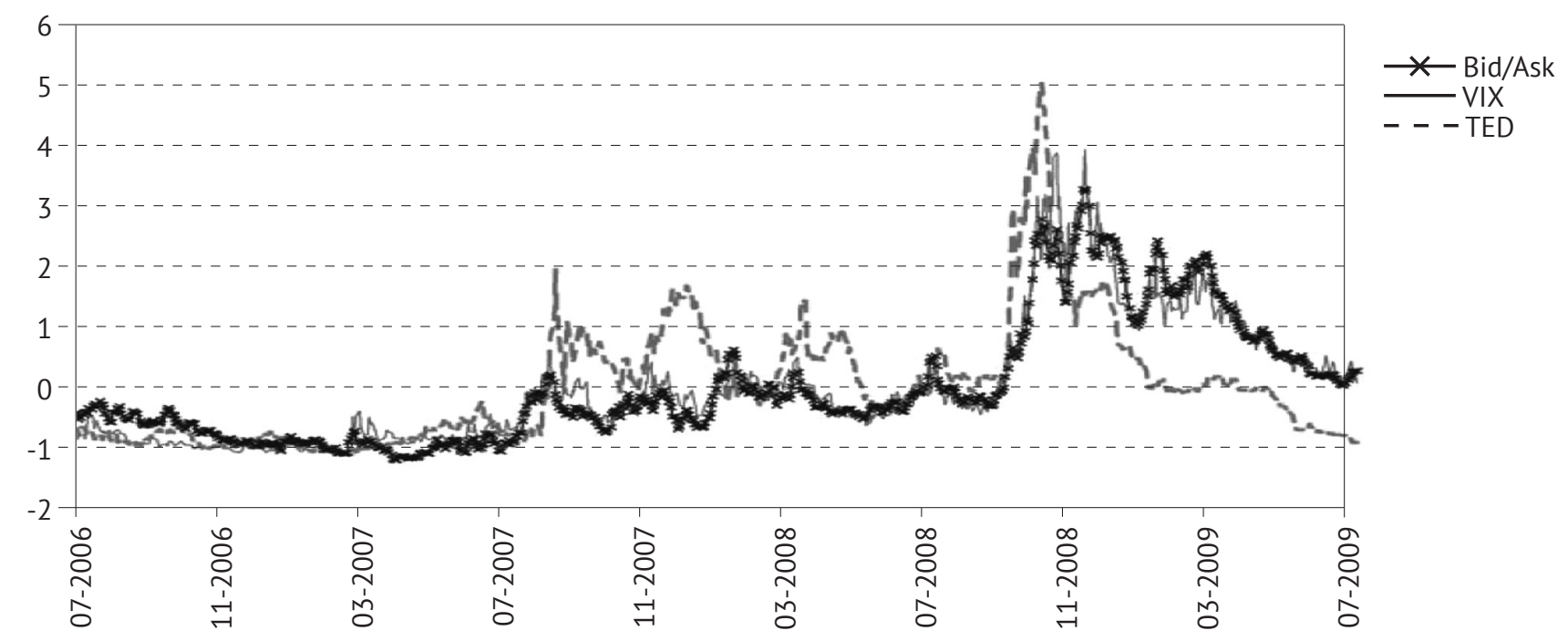

Note: The chart shows average bid-ask spread for large-cap U.S. stocks, the equity volatility index VIX, and the interest rate spread between LIBOR and Treasury bills (TED) from July 2006 to July 2009. Each of the series has been scaled to have a zero mean and a unit standard deviation.

Source: Pedersen (2009).

\section{Methodology}

As in our previous paper (Bricelj, Strašek, \& Jagrič, 2013), we first describe the concept of liquidity. Jorion (2007) defined three different forms of liquidity. The first form is defined as the ability of a company to pay its debts. The second form is used to describe the characteristics of a portfolio (asset liquidity) or a market (market liquidity). The third form defines the state of an economy from the monetary perspective. The relevant form for our research is the second form - that is, the definition of how readily available a certain asset is for trade.

From the discussion thus far, we can further define market liquidity as costs associated with trading an asset relative to its mid-price. Stange and Kaserer (2009) defined possible degrees of liquidity of an asset as "fully liquid", "continuously tradable”, “disruptively tradable”, and "illiquid”.

The availability of data often defines the methodology used in the research. Consequently, some models that incorporate liquidity risk are purely theoretical (Ernst, Stange, \& Kaserer, 2009), including models based on optimal trading strategies. The authors classified the applied models into three groups: models based in bid-ask-spread data, models based on transaction or volume, and models based on weighted spread data.

In our research, we used data on relative spread. Our models were based on those documented in the articles of Bangia Diebold, Schuermann, and Stroughair (1998, 1999) and upgraded according to Ernst, Stange, and Kaserer (2012) with the Cornish-Fisher expansion to estimate the quantiles of the distribution of spread and mid-price:

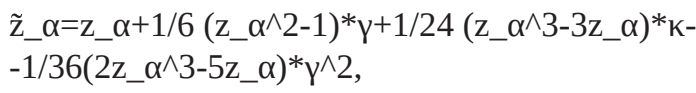

where $\gamma$ and $\mathrm{k}$ represent the skewness and kurtosis of a distribution. Considering the multiplicative effects of worst spread on mid-price returns, they proposed the following LVaR model:

$\operatorname{LVAR}=1-\mathrm{e}^{\wedge}\left(\tilde{\mathrm{z}} \_\alpha(\mathrm{r}) \sigma \_r\right)\left(1-1 / 2\left(\mu \_S+\tilde{z} \_\alpha(S) \sigma \_S\right)\right)$,

where $\tilde{z} \_\alpha$ (r) represents the quantile of the distribution of returns and $\tilde{z} \_\alpha(S)$ represents the quantile of the distribution of spread.

In our research, we calculated the volatility of returns using GARCH $(1,1)$. We opted for this method because, according to Engle (2001) and Bollerslev (2009), this type of GARCH model is often used in praxis. To calculate the dynamic variance, we used the following econometric model:

$\sigma \_{ }^{\wedge} 2=\omega+\alpha \_i \varepsilon \_(t-1)^{\wedge} 2+\beta \_i \quad \sigma \_(t-i)^{\wedge} 2$.

The crucial part of our research after the implementation of VaR and LVaR models was the testing for accuracy of these 
models using out-of-sample diagnostics, known as backtests. It can be assumed that, if a model does not pass these backtests, it is not sufficiently accurate, although it must be noted that the results of backtests vary depending of the characteristics of a portfolio (Alexander, 2008). Backtests are based on historical data with a fixed estimation period, which defines the sample used to estimate the VaR model parameters.

\section{Data Collection and Results}

We tested the effects of the global economic crisis on spreads with an ad-hoc ANOVA analysis of securities from four markets: the United States, Germany, Slovenia, and Korea. Using the ANOVA procedure we tested if the relative bid-ask spreads of securities changed in times of crisis - that is, if the change of the mean of those spreads was statistically significant. We calculated relative bid-ask spreads as the spreads between best ask and bid prices of securities, divided by the mid-prices of the observed securities:

$S=\frac{P_{a s k}-P_{b i d}}{P_{\text {mid }}}$

The table reports the $p$-values of ANOVA tests for our chosen securities. It is evident from the results that the relative bid-ask spreads differ in times of crisis. For 18 of the 20 chosen securities, we identified a statistically significant difference between the mean values of spreads before and after the start of the crisis, calculated as a $p$-value less than 0.05. In one case (GRVG) the $p$-value is marginal, but only because the data cover a short time before the crisis, due to the security splitting. Furthermore, a closer examination of results of our tests indicated that the spreads are larger in times of economic crisis than in times of economic stability.

Our database is comprised of four sets of securities, corresponding to the stock exchanges on which they are traded: Slovenian dataset, German dataset, Korean dataset, and American dataset. We summarized the characteristics of the chosen stock exchanges in Table 1.
Table 1 clearly shows how much the capital markets differ from one another. Some of the biggest stock exchanges operate on the foreign capital markets and are significantly larger than the Slovenian one.

In our research, we included five assets from each of the four capital markets - that is, five stocks from the Slovenian Prime Market Shares, five from the DAX 30 Index, five from the Dow Jones Industrial Average Index, and five from the KOSPI Composite Index. The data on assets consisted of price data (opening and closing maximum and minimum prices), volume data, and spread data (best bid/ask prices from the limit order book). We obtained the data for the Slovenian assets from the Ljubljana Stock Exchange and the data for foreign assets from Bloomberg. The data covered the period from January 2000 to April 2012 on a daily frequency.

Table 2 presents the data analysis. We based the analysis on mid-price logarithmic returns. The reason we chose the mid-price returns is because they are used in VaR and LVaR models as well as in most types of backtests we applied. In Table 2, $n$ is the number of trading days, $\mu$ is the mean of logarithmic returns, Max and Min are the maximum in minimum value of returns in the sample, $\sigma$ is the standard deviation of returns, $\gamma$ is the coefficient of skewness, $K$ is the coefficient of kurtosis, and JB is the $p$-value of the Jarque-Bera test.

We chose the assets for our research in such a way that they best represented the economic landscape of a chosen economy while being diversified at the same time. We also tried to harmonize the choice of assets among the four capital markets. Two particular criteria were used in the choice of the final five. First, the data on the assets must cover a long enough period to encompass times of economic upturn and downturn. Second, the data must not contain bigger anomalies, such as stock splits or longer periods of no trading activity. In one case (KRKG), there was a stock split in September 2007. We chose to incorporate into our research only the data after the split as the other Slovenian stocks not chosen were far less traded and, therefore, presumed far less liquid than the one with the anomaly.

Table 1. General characteristics of the chosen stock exchanges in 2011

\begin{tabular}{lcccc} 
& Deutsche-Boerse & $\begin{array}{c}\text { Ljubljana Stock } \\
\text { Exchange }^{\text {a }}\end{array}$ & Korea Exchange & $\begin{array}{c}\text { New York Stock } \\
\text { Exchange }\end{array}$ \\
\hline Market capitalization [US\$bn] & 1185 & 6,316 & 996 & 11796 \\
\hline Number of listed companies & 746 & 76 & 791 & 2308 \\
\hline Trade value [US\$bn] & 1758 & 0,511 & 2029 & 18027 \\
\hline
\end{tabular}

Notes: ${ }^{a}$ Data for Slovenia are converted to USD using the closing exchange rate on 30 December 2011: EUR/USD = 1,29610.

Sources: http://www.ljse.si, http://www.world-exchanges.org/ 
Table 2. Data Analysis of Logarithmic Mid-price Returns

\begin{tabular}{|c|c|c|c|c|c|c|c|c|c|}
\hline Code & Description & $n$ & $\mu$ & Max & Min & $\sigma$ & $\gamma$ & $x$ & $J B$ \\
\hline GRVG & Gorenje, d.d. & 3045 & $-0,00023$ & 0,097 & $-0,094$ & 0,016 & $-0,041$ & 7,721 & 0,000 \\
\hline KRKG & Krka, d.d. & 1122 & $-0,00078$ & 0,084 & $-0,113$ & 0,017 & $-0,380$ & 8,863 & 0,000 \\
\hline LKPG & Luka Koper, d.d. & 3045 & $-0,00014$ & 0,108 & $-0,098$ & 0,016 & $-0,104$ & 8,044 & 0,000 \\
\hline MELR & Mercator, d.d. & 3034 & 0,00021 & 0,110 & $-0,094$ & 0,016 & 0,142 & 9,157 & 0,000 \\
\hline PETG & Petrol, d.d. & 3047 & 0,00012 & 0,128 & $-0,106$ & 0,015 & 0,277 & 13,501 & 0,000 \\
\hline BAYN.DE & Bayer AG & 3102 & 0,00006 & 0,334 & $-0,189$ & 0,022 & 0,803 & 25,922 & 0,000 \\
\hline BMW.DE & BMW AG & 3087 & 0,00026 & 0,135 & $-0,126$ & 0,022 & 0,055 & 6,623 & 0,000 \\
\hline DAI.DE & Daimler AG & 3098 & $-0,00021$ & 0,175 & $-0,143$ & 0,023 & 0,175 & 8,059 & 0,000 \\
\hline TKA.DE & ThyssenKrupp AG & 3086 & $-0,00018$ & 0,165 & $-0,174$ & 0,024 & $-0,108$ & 7,205 & 0,000 \\
\hline SIE.DE & Siemens AG & 3112 & $-0,00006$ & 0,166 & $-0,165$ & 0,024 & $-0,068$ & 7,312 & 0,000 \\
\hline 000120.KS & CJ Korea Express Co. & 2714 & 0,00007 & 0,254 & $-0,627$ & 0,039 & $-1,360$ & 33,409 & 0,000 \\
\hline 000210.KS & Daelim Industrial Co. & 2862 & 0,00076 & 0,465 & $-0,274$ & 0,038 & 0,440 & 13,747 & 0,000 \\
\hline 000240.KS & Hankook Tire Co. & 2877 & 0,00093 & 0,154 & $-0,141$ & 0,031 & 0,254 & 4,833 & 0,000 \\
\hline $000270 . K S$ & Kia Motors Corp. & 2837 & 0,00085 & 0,214 & $-0,296$ & 0,032 & $-0,258$ & 8,487 & 0,000 \\
\hline 005930.KS & Samsung Electr. Co. & 2925 & 0,00054 & 0,140 & $-0,146$ & 0,026 & 0,029 & 6,689 & 0,000 \\
\hline BA & The Boeing Co. & 2967 & 0,00019 & 0,180 & $-0,173$ & 0,024 & $-0,039$ & 8,613 & 0,000 \\
\hline$\underline{\mathrm{HPQ}}$ & Hewlett-Packard Co. & 2920 & $-0,00020$ & 0,203 & $-0,285$ & 0,031 & $-0,363$ & 13,250 & 0,000 \\
\hline $\mathrm{KO}$ & The Coca-Cola Co. & 2959 & 0,00008 & 0,100 & $-0,144$ & 0,016 & $-0,116$ & 9,164 & 0,000 \\
\hline PFE & Pfizer Inc. & 2920 & $-0,00012$ & 0,116 & $-0,161$ & 0,020 & $-0,228$ & 8,596 & 0,000 \\
\hline XOM & Exxon Mobil Corp. & 2840 & 0,00027 & 0,172 & $-0,160$ & 0,019 & $-0,046$ & 12,794 & 0,000 \\
\hline
\end{tabular}

Source: Authors' calculations.

Regarding the start of the crisis, in our analysis, we defined the start of the American crisis in August 2007 and the start of the European crisis and the rest of the world in September 2008. The results are shown in Table 3.

We analysed the collected data and corrected smaller anomalies than those discussed above. From the data on Slovenian stocks, we omitted those days where errors occurred in the calculation of mid-price. These occurred due to either the lack of trading on a particular day or mismatches in limit order data. From the data on foreign stocks, we omitted non-tradable days. Finally, we applied an automatic filter, which omitted the days with a recorded negative bid-ask spread as well as days where the bid-ask spread exceeded the mean bid-ask spread of the sample by five standard deviations. We assumed that such bid-ask spread outliers cannot be part of the data but must be caused by errors in the limit order data.

To produce the VaR and LVaR estimates in our research, we used the following procedures. We used a 20-day rolling procedure to produce the mean values of returns and spread. For the GARCH variances, we used a 250-day rolling procedure. The reason behind the larger data window was that our tests of GARCH coefficients showed that they are unstable when using a smaller data window. For the quantiles of the Cornish-Fisher expansion, we used a 500-day rolling procedure because estimates on smaller data windows are susceptible to effects of outliers in the data (Ernst et al., 2012).

We tested the accuracy of VaR and LVaR models using an unconditional coverage backtest. The exceedances in LVaR

Table 3. ANOVA Analysis of the Relative Bid-ask Spread Pre-and Post-crisis

\begin{tabular}{lllll}
\hline GRVG & KRKG & LKPG & MELR & PETG \\
\hline 0.00000 & 0.09300 & 0.00000 & 0.00000 & 0.00000 \\
\hline BAYN.DE & BMW.DE & DAI.DE & TKA.DE & SIE.DE \\
\hline 0.00000 & 0.58100 & 0.00920 & 0.00000 & 0.04520 \\
\hline $000120 . K S$ & $000210 . K S$ & $000240 . K S$ & $000270 . K S$ & $005930 . K S$ \\
\hline 0.00000 & 0.00000 & 0.00000 & 0.00000 & 0.00000 \\
\hline BA & HPQ & KO & PFE & XOM \\
\hline 0.00000 & 0.00000 & 0.00000 & 0.00000 & 0.00000 \\
\hline
\end{tabular}

Source: Authors' calculations. 
models were identified by comparing model forecasts with realized losses that were calculated as realizable net returns when liquidating a position (Ernst et al., 2012):

[rnet]_t $=\ln \left(\mathrm{P} \_\mathrm{t} / \mathrm{P} \_(\mathrm{t}-1)\right)-\ln \left(1-1 / 2 \mathrm{~S} \_\mathrm{t}\right)$.

\section{Conclusions}

The analysis of market spreads confirmed that the financial crisis affected markets deeply and over the whole spectrum of finance, from actual spreads on tradable assets to arising liquidity issues on bond markets during the crisis as well as to firms' funding liquidity. Furthermore, the crisis accentuated the problems associated with bond yields from Eurozone country bonds and their inherent susceptibility to self-fulfilling crises.

The analysis of the spreads also confirmed that the effects of the financial crisis radiated from the United States and manifested in European markets with a delay of more than a year, as seen in the analysis of spreads. This is also well documented in the accuracy of LVaR and VaR models tested on select markets.

The results from the LVaR models were accurate for four out of five Slovenian stocks, but the VaR models underestimated risk in all cases. LVaR models overestimated risk for all five German stocks, but VaR models showed a high degree of accuracy. The results of unconditional coverage tests for the Korean stocks showed that the LVaR and VaR models were accurate in three out of five cases. Finally, LVaR models were accurate for all five of the American stocks, according to unconditional coverage tests, but VaR models were less accurate.

Backtests for the GARCH LVaR models showed that they were accurate on four out of five Slovenian stocks whereas GARCH VaR models underestimated the risk. GARCH LVaR models were accurate for three German stocks; GARCH VaR models also underestimated the risk. The results for the Korean stocks showed that the GARCH LVaR models were accurate in $80 \%$ of the cases and the GARCH VaR models in $60 \%$. For the American subset, the GARCH LVaR models were accurate for two of the five American stocks while the GARCH VaR model backtests showed similar results as in all the prior stocks.

\section{References}

1. Alexander, C. (2008). Market risk analysis, volume IV: Value-at-risk models. Chichester: John Wiley \& Sons Ltd.

2. Attinasi, M. G., Checherita C., \& Nickel C (2009). What explains the surge in Euro area sovereign spreads during the financial crisis of 2007-09. Working paper series.

3. Bai, J., Julliard, C., \& Yuan, K. (2012). A forensic analysis of liquidity and credit risk in European sovereign bond markets. Retrieved from http://www.frbsf.org/economic-research/events/2013/january/federal-reserve-day-ahead-financial-markets-institutions/files/ Session_1_Paper_2_Bai_etal_forensic.pdf

4. Bangia, A., Diebold, F. X., Schuermann, T., \& Stroughair, J. D. (1998). Modeling liquidity risk with implications for traditional market risk measurement and management. Wharton Financial Institutions Center, Working Paper.

5. Bangia, A., Diebold, F. X., Schuermann, T., \& Stroughair, J. D. (1999). Liquidity on the outside. Risk, 12, 68-73.

6. Barrios, S., Iversen, P., Lewandowska, M., \& Setzer, R. (2009). Determinants of intra-euro area government bond spreads during the financial crisis. Brussels: European Communities.

7. Beber, A., Brand, M., \& Kavajez, K. (2006). Flight-to-quality or flight-to-liquidity? Evidence from the euro area bond market. National Centre of Competence in Research Financial Valuation and Risk management, WP No. 309.

8. Bernstein, A., Hughson, E., \& Weidenmeier, M. (2011). Central banking, liquidity, and financial crises. Retrieved from http://isites. harvard.edu/fs/docs/icb.topic881224.files/Berinstein\%20paper\%20Central\%20Banking\%20Liquidity\%20and\%20Financial\%20 Crises.pdf

9. Bollerslev, T. (2009). Glossary to ARCH (GARCH). CREATES Research Papers.

10. Bricelj, B., Strašek, S., \& Jagrič, T. (2013). Vpliv likvidnostnega tveganja na izračun tvegane vrednosti. Management, 8(3), $183-197$.

11. Brunnermeier, M., \& Pedersen, L. (2009). Market liquidity and funding liquidity. Review of Financial Studies, 22. http://dx.doi. org/10.1093/rfs/hhn098

12. Checherita, C., Attinasi, G. M., \& Nickel, C. (2010). What explains the surge in euro-area sovereign spreads during the financial crisis of 2007-09? Retrieved from VOX CEPR's Policy Portal at http://www.voxeu.org/article/how-financial-crisis-raised-eurozone-bondspreads

13. De Grauwe, P. (2011). The governance of a fragile Eurozone, economic policy. CEPS working documents. Retrieved from http://www. ceps.eu/book/governance-fragile-eurozone

14. De Grauwe, P., \& Ji, Y. (2013). Self-fulfilling crises in the Eurozone: An empirical test. Journal of International Money and Finance, 34, 15-36. http://dx.doi.org/10.1016/j.jimonfin.2012.11.003 
15. ECB. (2009). What explains the search in euro area sovereign spreads during the financial crisis of 2007-09? Working paper Series No. 1131.

16. Engle, R. (2001). GARCH101: The use of ARCH/GARCH models in applied econometrics. Journal of Econometric Perspectives, 15(4), 157-168. http://dx.doi.org/10.1257/jep.15.4.157

17. Ernst, C., Stange, S., \& Kaserer, C. (2009). Measuring market liquidity risk-Which model works best? CEFS Working Paper.

18. Ernst, C., Stange, S., \& Kaserer, C. (2012). Accounting for non-normality in liquidity risk. The Journal of Risk, 14(3), 3-21.

19. Gilchrist, S., \& Zakrajšek, E. (2012). Credit spreads and business cycle fluctuations. The American Economic Review, 102(49, $1692-1720$.

20. Guidolin, M., \& Tam M. Y. (2010). A yield spread perspective on the great financial crisis: Break-point test evidence. Research Division Federal Reserve Bank of St. Louis Working Paper Series.

21. Jorion, P. (2007). Value at risk: The benchmark for controlling market risk (3 ${ }^{\text {rd }}$ ed.). New York: McGraw-Hill Publishing Co.

22. Mehrling, $P$ (2013). Liquidity: The real cause of the financial crisis. Retrieved from http://webcache.googleusercontent.com/search?q=cache:8K9njmKyl58J:www.gailfosler.com/liquidity-the-real-cause-of-the-financial-crisis+\&cd=6\&hl=sl\&ct=clnk\&gl=si

23. Pedersen, L. H. (2009). When everyone runs for the exit. International Journal of Central Banking, 5(4), $177-199$.

24. Pringle, R., \& Carver, N. (2009). RBS reserve management trends 2009. London: Central Banking Publications.

25. Stange, S., \& Kaserer, C. (2009). Market liquidity risk-An overview. CEFS Working Paper.

26. Strahan, P. (2012). Liquidity risk and credit in the financial crisis. FRBSF Economic Letters, 15.

27. Viral, V., \& Pedersen, L. (2004). Asset pricing with liquidity risk. NBER Working Paper No. 10814.

\section{Authors}

Sebastjan Strašek is a full professor of economic policy at the Faculty of Economics and Business, University of Maribor. He received his B.A. in economics from the University of Zagreb, Croatia, and his Ph.D. in economics from the University of Maribor. He has written widely on various aspects of financial crises, including business cycles, behaviour of capital markets, and different aspects of stock trends. He is currently the chair of the Department of Economic Policy at the Faculty of Economics and Business in Maribor.

Bor Bricelj is an assistant in the field of economic theory and economic policy at the University of Maribor's Faculty of Economics and Business. His research is mainly focused on the fields of macroeconomics and finance, where his prime interest is in the application of statistical and econometric techniques to model the data and provide solutions to contemporary economic problems.

\section{Problematika likvidnosti in cenovnih razponov - primerjava kapitalskih trgov}

\section{Izvleček}

Finančne krize so tesno povezane z likvidnostnimi težavami, ki izhajajo iz sprememb poslovanja na borzah. V tem članku analiziramo likvidnostne težave $v$ času ekonomskih kriz. Likvidnostne učinke analiziramo na podlagi informacij o cenovnem razponu med ponujeno in povpraševano ceno naložbe. Predpostavljamo, da v času kriz obstaja pozitivna povezava med prevzemanjem tveganj in večanjem cenovnih razponov. V članku uvedemo likvidnost v standardno analizo tvegane vrednosti, pri tem pa za izračune volatilnosti uporabimo metodo GARCH. O primerjavi rezultatov po naborih delnic ugotavljamo, da velikost kapitalskih trgov ne vpliva na rezultate modelov, zato ugotavljamo tudi, da se po likvidnostnih modelih VaR ob upoštevanju predpostavk raziskave primerno ocenjujejo tržna tveganja.

Ključne besede: likvidnost, finančne krize, modeli GARCH VaR 